\title{
An Alternative Model of a Profession for Librarians
}

\begin{abstract}
The traditional model of a profession based on the literature of sociology is presented and critiqued. The model is found to include elements which encourage resistance to change. An alternative model is proposed, based on the open systems paradigm from General Systems Theory, which is more hospitable to change. The alternative is applied to librarianship, and some of its implications are discussed.
\end{abstract}

W HILE A GOOD DEAL OF LIBRARY LITERATURE has been devoted to the professional status of librarianship, one fundamental question about professionalism has rarely, if ever, been addressed with the explicitness and detail it deserves. This question is whether or not the established model of professionalism is an ideal to which librarianship should aspire. Until recently to ask such a question would have bordered on sacrilege. There was only one model of a profession, and it was based on the two venerable professions of medicine and law. For a librarian, a member of an occupation which could not seem to cross the professional line of demarcation no matter how hard it tried, to challenge the traditional concepts of professionalism seemed a classic example of sour grapes. Now, however, because of longterm developments and current scandals, the two godheads of professionalism have begun to look mortal. We have slowly come to the realization that our

Gardner Hanks is a student in the School of Library and Information Science, State University of New York at Albany. C. James Schmidt is director of libraries, State University of New York at Albany. medical and legal systems are social disaster areas and that, in part, the professions charged with their upkeeping are responsible for their deterioration. By using the traditional rhetoric of professionalism to oppose needed social changes, we have overlooked the fact that even law and medicine are, in many ways, turning away from the traditional professional model.

Thus, we can now look at the traditional professional model with a skepticism and realism that was not possible even a few years ago. When we do, we find there is an intrinsic conflict between the model of professionalism to which librarianship has aspired and the ability of this model to accommodate change. The traditional paradigm reinforces conservatism in the face of change. For example, new developments in theory are seen as threats to the established body of knowledge. Increased complexity in library organizations is feared because it is seen as reducing professional autonomy (to the extent that librarians ever enjoyed any). New types of agencies that provide information services to groups who have not been adequately served by the library, and are alienated from it, are resisted 
by librarianship as encroachments on its professional monopoly. Forces of change, in other words, become the antitheses of the basic characteristics of professionalism.

The traditional paradigm of professionalism encourages a static condition which is incompatible with the dynamism inherent in a truly client-centered (including non-user clients) professional orientation. This essay is an attempt to detail the faults of the traditional model of professionalism, to examine why librarianship cannot and should not aspire to this model, and to suggest an alternative which is both more professional, in the sense of a profession as a calling, and more user oriented. This essay may also shed some light on the conflicts which are endemic to an emerging profession.

\section{Characteristics of a Profession}

The literature of the sociology of the professions includes many attempts to list the distinctive features or differentia of a profession. ${ }^{1}$ The various attempts to delineate the characteristics of a profession began with Flexner in 1915, continued through the fifties with the work of Cogan, Greenwood, and Hughes, and extended through the sixties and seventies with the work of Goode, Vollmer and Mills, Parsons, Etzioni, and Paval$\mathrm{ko.}^{2-10} \mathrm{~A}$ review of these and other sources suggests the following catalog of attributes of a profession:

1. An organized body of systematic and theoretical knowledge

2. Primary orientation to the community interest rather than to individual self-interests

3. Autonomy

4. Group control of practice through licensure and codes of ethics

5. Professional organization

6. Monopoly

7. Community sanction

After reviewing these efforts to define a profession, Barber concludes: "Theo- retical and methodological consensus is not yet so great among sociologists that there is any absolute agreement on the definition of the professions."11 What does seem to receive unanimous agreement from the more recent writers is the concept of professionalism as a continuum, not a dichotomy: that is, the characteristics of a profession may be possessed by an occupational group in varying degrees, and the degree to which any characteristic is present in such a group may vary over time. In the classic essay on professionalism vis-à-vis librarianship, Goode makes this point:

Any traits used in the definition of the term "profession" must be conceived as variables, forming a continuum along which a given occupation may move. Instead of the dichotomy of "professional/non-professional," we use the variable of "professionalism," and we may ask how far an occupation has moved in the direction of increased or decreased professionalism. ${ }^{12}$

What is clear from this list of attributes, and from other similar lists, is that law and medicine have served as the paradigms on which such lists have been based. However, it has been pointed out by Becker that there is a substantial gap between the symbol and the reality, even in the paradigmatic cases. ${ }^{13}$ Doctors often surrender individual autonomy for group practices, clinics, research and training, public health, and other types of nonindividualistic-type practices. Doctors do not in fact monopolize health care services but rather share these functions, albeit reluctantly, with osteopaths and chiropractors, among others.

Thus, the model of professionalism appears to be wanting in some respects and, in any case, is still not based on consensus. Rather than abandon this model, however, let us first see how it fits librarianship, and then, informed by this application, examine specific criticisms and propose an alternative. 


\section{Librarianship: A Profession?}

In his essay Goode concluded that librarianship was not a profession and not likely to become one. His argument was based on the assumption that prolonged training in a body of abstract knowledge and a service orientation are the two "central generating traits" of a profession. ${ }^{14}$ The specific knowledge which a librarian must have is not clearly defined, according to Goode, and the service orientation, in the case of the librarian, usually connotes a passive helping, i.e., simple reaction to the patron's expressed needs, rather than a more active sense of service in the manner of doctors and lawyers.

A second analysis of librarianship as a profession, by Bundy and Wasserman, viewed librarians in terms of three major structural relationships: with clients; with the institution in which librarians perform; and with their professional group. In all three relationships, the authors judged librarians to lack those traits which mark professionals. Librarians do not create or demand the kind of institutional environment which optimizes professional commitment and minimizes employee requirements. Finally, the major professional organization for librarians, the American Library Association, has assumed a primary focus which is political rather than professional. Thus, librarianship was seen as incompletely professionalized and on the margin of full professionalization. ${ }^{15}$

\section{Critique of the Model of Professionalism}

If librarianship is a marginal profession, a semi-profession, or is, in other words, possessed of less than fully developed professionalism, the question arises as to where it should go from here. The issue of where librarianship should go in its development along this continuum, however, is logically preced- ed by the question of whether it is desirable to pursue the traditional model of professionalism however elusive or ill-defined. In short, if the traditional model can be shown to be defective, and inappropriate to librarianship, should it not be discarded and some alternative model developed and aspired to? This rhetorical question is meant to suggest that the traditional model is defective and, therefore, dysfunctional to the professionalization of librarianship. Five specific defects in the model will be discussed below.

The first weakness in the model is the notion of an organized body of knowledge. There is a somewhat naive presumption that the systematic body of theory which supports professional practice implies a commitment to rationality and, therefore, to scientific mindedness, which will be manifest in a willingness to change. ${ }^{16}$ This view does not differentiate enough among different types of knowledge (some of which are nonscientific); and it "overemphasizes the role of scientific knowledge and its attendant consequences, such as rationality and readiness for change."17 The unwillingness of many so-called professions to incorporate new developments suggests that rationality and susceptibility to change may not be the dominant characteristic or happy consequence of their "bodies of knowledge."

A second weakness of traditional professionalism is the potential negation of the concept of community service by other elements of the model. It is not unusual, for example, for the concept of autonomy to clash with and override that of community interest. A case in point was the New York City teachers' strike in the fall of 1968. The teachers walked out because they felt inter alia that community control of the schools threatened their independence and free judgment in the classroom. ${ }^{18}$ In a similar and continuing case, the medical profession has put up a stubborn fight 
against much-needed national health care insurance and peer review mechanisms because such programs are seen as seriously limiting a doctor's autonomy. While it may be that all conflicts between community service and other elements of professionalism are not resolved in favor of the more self-serving interests, examples among the professions have been common enough to create nationwide concern about the motives of many professional groups. Thus, the conflict between the concept of community interest and other aspects of the professional model is perhaps the most visible weakness of the traditional model of a profession.

Third, the traditional model places a premium on autonomy for the practicing professional, as in medicine and law. Indeed, Friedson goes so far as to say: "From the single condition of selfdirection, or autonomy, I believe we can deduce or derive virtually all the other institutional elements that are included in most definitions of professions."19 The epitome of this idealized autonomy is a fee-for-service client-professional relationship. It is clear, however, that fewer and fewer professionals in any field are practicing in such totally individualized patterns. Both doctors and lawyers are increasingly found practicing in organizational (bureaucratic) settings, such as clinics, hospitals, large law firms, and governmental agencies. Furthermore, as a society becomes more complex and urbanized, it also becomes more bureaucratized. Of course, this trend is not without its problems for professionalization, ${ }^{20}$ but the tendency in many occupational groups is clearly away from individual professional practice and toward group practices and/ or organizational settings.

Another aspect of autonomy as it is used in the traditional professional model is that it is assumed to be a quantitative phenomenon-the question is how much does an occupational group have. Bureaucratization suggests that qualitative dimensions of autonomy may be of equal, if not greater, importance in the future. The question of the future will not be "how much?" but rather "what kind?" Friedson's concept of dominance, ${ }^{21}$ developed in his studies of the medical profession, suggests one conceptualization of qualitative aspects of autonomy.

In the case of the health occupations, medicine occupies a unique position relative to all the other allied occupational groups. It has the authority to direct and evaluate the work of others without in turn being subject to formal direction and evaluation by them. ${ }^{22}$

While the division of the labor force in libraries is not yet so variegated that the concept of dominance developed for the study of the health occupations has direct applicability, the distinction between quantitative and qualitative dimensions of autonomy is viable for librarianship. For example, in what respects do library procedures impose a uniformity on all librarian-patron interaction? To what extent are librarians themselves treated differentially by the organization of which they are a part?

A fourth weakness in the traditional model of a profession is the notion of monopoly. As Rueschemeyer points out, this "assumes a high degree of societal and intraprofessional consensus." 23 This consensus, however, does not occur. What is more likely is a high degree of intraprofessional conflict, except where serious extraprofessional threats exist. ${ }^{24}$

The fifth principal weakness of the traditional model is the issue of community sanction and the implication that there is a marked differentiation in competence between the client and the professional. ${ }^{25}$ This is more likely to be true in the case of medicine-although not always-and is certainly less true of law and some of the human relations occupations. ${ }^{26}$ As a result of the vari- 
ance in the competence differential between client and professional, it is probable that, contrary to some sociological speculation, clients are increasingly given to "shopping around" and to evaluations of professional services. That this occurs suggests some competence, however ignorant or informed, on the part of clients to make qualitative judgments about the professional services they receive.

The traditional model does have some basic flaws. The five discussed here can be summed up by the notion that the model is not sufficiently dynamic to absorb the changes that are occurring both in the community as a whole and in the professions themselves. Given this unadaptability, it would seem reasonable to conclude that the model would be dysfunctional for any occupational group whose environment is undergoing rapid and important changes. The discussion below turns to a presentation of some of the changing conditions in librarianship, changes which suggest a need for an alternative professional model.

\section{Librarianship: The Changing ENVIRONMENT}

Social institutions are affected by movements in the society around them, and the library is no exception. Though it would be possible to list any number of social changes which are affecting libraries, we will discuss only four: the media revolution; the coming of age of computer technology; the demand for community control; and the increasing awareness of the social responsibilities of libraries and librarians. Each of these has important consequences.

First, the media revolution. The crucial issue for librarianship in the "multimedia age" is how libraries should relate to the whole contemporary machinery of public communication. If the dire predictions of some McLuhanites have not all been realized, it is still true that when it comes to reading, the medium is the message. Should libraries focus only on the literate groups in the population? This issue was raised by the Public Library Inquiry of the Social Research Council in 1948, ${ }^{27}$ and there seem to be no more consensually based answers today than there were then. While this issue is generally seen as more crucial for public libraries, analogies exist for academic libraries in the development of learning resources centers (in lieu of libraries) in community colleges, liberal arts colleges, and on some university campuses, as well as in the transformation of school libraries into instructional resource centers. The ubiquity of television compounds the problem, as does the increasing availability of cable television.

The awesome power of computer technology is also a major force of change in the library work environment. The potential of computers has implications not only for internal library operations but also for library services. As data transmission rates drop and as banks of cataloging data in computerreadable form grow, the prospects of on-line shared cataloging systems are being realized. ${ }^{28}$ This development is anxiously awaited by some library administrators who believe it will help reduce the soaring costs of preparing library materials for users, but it has obvious conflict potential for those people whose professional self-image is tied up with nonmechanical individualized methods of cataloging materials. In the same manner, blanket order plans and other mechanizable means of acquiring materials are welcomed by administrators but viewed with alarm by those whose professional existence is bound up with title-by-title methods of selecting and collecting materials.

Another dimension of the computer revolution is the growing demand for services from computer-readable data bases-bibliographic and nonbiblio- 
graphic. In effect, a new medium has been added to those already competing for attention and resources. This new medium, however, brings along with it staggering problems of software development, hardware expense, and new, unfamiliar occupational categories.

One manifestation of the demand for these services is the growing concern for what used to be called computer utilities and are now called mass information utilities. ${ }^{29}$ Parker writes of them in this way:

This new communication medium can be described as looking like a combination of a television set and a typewriter, functioning like a combination of a newspaper and a library, and permitting a communication network that is something of a combination of a telephone and a telegraph system. It has one radical new property that previous mass media lack: what is transmitted over the communication channel is controlled more directly by the receiver rather than the sender of the message. ${ }^{30}$

A third major force in the changing environment of librarianship is represented by what has been called "community control." In its usual form this means at least direct community participation on governing boards of social and political agencies, if not complete community control of these agencies or their localized outlets, such as elementary schools or branch libraries. A moderate statement of this point of view for libraries by Field proposes that "the librarians should be given a budget to use for programs that the staff, with the help of the community, decide are legitimate and necessary for the library. ..." ${ }^{11}$

Fourth and finally, librarians, as well as other occupational groups, are developing an increased sensitivity to their social responsibilities. The establishment of the Social Responsibilities Round Table (SRRT) by the American Library Association is evidence of this concern. Let it be acknowledged here that SRRT was born in haste and with much pain, but the important point is that there is now an officially articulated awareness of these responsibilities. Social responsibilities, or "the relationships that librarians and libraries have to nonlibrary problems that relate to the social welfare of our society," 32 have been recognized as an important part of librarianship's ever-changing environment.

There are, of course, other sources of change in the milieu of librarianship that could be included here. However, these four examples make it clear that libraries and librarians face enormous technological and social changes both inside and outside the library. Librarianship is in the process of becoming something other than it has been.

\section{An Alternative: The Open \\ Systems Model of Professionalism}

To recapitulate the argument to this point: we have argued that the traditional model of a profession is deficient in several ways, the most important of which is its discouragement of change; that librarianship is a marginal profession in terms of that model; and that there are major forces of change at work in the library environment; all of which suggest that the traditional model of a profession does not meet the needs of librarianship and that an alternative model of a profession is essential if this concept is to be applied to librarians or to any occupational group whose environment is undergoing rapid and massive changes.

In developing an alternative model of a profession, we have based our work on the ideas of General Systems Theory (GST) as expressed by von Bertalanffy, Buckley, Kast and Rosenzweig, and Katz and Kahn. ${ }^{33-36}$ Basically, GST defines two types of systems: closed and open. Closed systems exist in the realm of the physical sciences; they 


\section{Open System Characteristic}

1. Input-throughput-output cycle

2. Feedback

\section{Negative entropy}

4. Dynamic equilibrium

5. Differentiation

6. Equifinality

\section{Professional Characteristic}

1. Interdependency between the profession and the community

2. Constant communication between the profession and the community concerning the needs of the community, the ways in which the profession can meet these needs, and the effectiveness of professional activities that are in operation

3. Security based on social, political, and economic support of the community

4. Ability to adapt to changes in the social environment

5. Specialization

6. Flexibility of methods; creativity

Fig. 1

Open System and Professional Characteristics

tend to be governed by absolute laws; and they are characterized by a tendency toward a static equilibrium, i.e., they cannot grow or adapt to changes in their environment.

Open systems, on the other hand, interact extensively with their surroundings. They import energy from their environment, transform this energy into some product or service, and export the product or service back into the environment. The export creates more energy in the environment which can be imported to repeat the same input-throughput-output cycle. Another important input that is typical in open systems is feedback, information from the environment that indicates general conditions of the system's surroundings and also the effects that the system's activities are having on these conditions. Besides the cycle of input-throughput-output, and feedback, open systems are also characterized by negative entropy, i.e., the ability to store some of the energy that they input. This stored energy can then be used when emergency situations arise.

In addition to the traits described above, open systems also typically have a dynamic equilibrium, that is, they have the ability to adapt to alterations in environmental conditions through growth or other internal changes. Moreover, because the various functions of open systems can become quite complex, they often can develop specialized parts to perform different functions. This process is known as differentiation. Lastly, open systems are characterized by equifinality, the ability to reach a given condition by several different paths. From these major characteristics of open systems, ${ }^{37}$ it can be deduced that biological organisms are typical examples of this type of system, but it is also obvious that social organizations and institutions may exhibit the qualities of open systems.

Though it would be unfair to characterize the traditional model of a profession as a totally closed system, this model does tend to picture professions as untouched by the concerns and needs of a society which serves as their environment. Only the attribute of community interest within the traditional model opens it to the environment, but, as we have pointed out above, even this one open quality tends to be contradicted and overridden by other characteristics in the model.

The model of professionalism we propose, then, is one that recognizes that a profession, as a social phenomenon, must interact with its environment. The characteristics of open systems professionalism are based on the characteristics of open systems, as shown in Figure 1.

In terms of librarianship, such a 
model would mean a primary commitment to users and a primary concern for information. Open systems librarianship would import energy from the environment (the community) in the form of money, social and political influence, and raw information. Then, using feedback about the needs of the community, librarians would transform this energy into library services which would be released back into the environment. The community would in turn generate more energy (information) and feedback which would be imported for repetition of the cycle.

\section{IMPLICATIONS OF OPEN \\ SYSTEMS LIBRARIANSHIP}

A primary commitment to users and a primary focus on information have six important implications for libraries. First, such a philosophy would result in libraries which are concerned with their clients both in terms of time and in terms of "space." Lefton and Rosengren call these two dimensions longitudinality (time) and laterality (space). Longitudinality is defined as the period of time during which an organization is interested in its clients-short, as in the case of an emergency room in a hospital, and indefinite, as in the case of a long-term psychiatric facility. Laterality is defined as the number of aspects of the client as a person which are of concern to the organization-again, the contrast between the emergency room and psychiatric care in an outpatient setting. In the latter case the organization concerns itself with the totality of the client as a person in society. ${ }^{38}$

Libraries have historically professed a high longitudinal and a high lateral orientation. However, functionally they have operated as high longitudinal but low lateral, because traditionally libraries have had little interest in the needs of the public other than their reading habits. Maximized laterality requires that other behavior besides that of read- ing be regarded as organizationally relevant for libraries.

A primary commitment to clients and a primary orientation to information, in terms of objectives and in terms of services, would make libraries high both on longitudinality and on laterality. For example, high laterality would suggest that lack of literacy on the part of potential library users is a viable rationale for developing an appropriate library service. Similarly, lack of adequate information about basic welfare benefits and facilities or legal rights would become a valid basis for initiating a library program to meet these needs.

The need for the library to achieve a high lateral as well as a high longitudinal concern for its clientele suggests that a second major consequence of open systems librarianship would be the development of more client-centered roles for librarians, and the concurrent deprofessionalization of functional roles, such as cataloging and reference. Already the activities of children's librarians, young adults' librarians, adult services librarians, community coordinators, ${ }^{39}$ subject bibliographers ${ }^{40}$ and special librarians have been developed around the needs of specific groups of clients within the community. Because these librarians have been able to concentrate their attention on particular subgroups of the population rather than dealing with general problems, they have been able to learn more about their clientele's problems and interests, and have built special programs around these needs. Such customized service would be the hallmark of the open systems library. Client-centered service would be expanded to include every major social, vocational, and intellectual group in the community.

At the same time that the open systems library would be requiring new client-centered roles for librarians, it would be phasing out the traditional media-centered roles as professional ac- 
tivities. The first step in this deemphasis would be the replacement of the traditional functional organization of the library with one based on the types of clients served. ${ }^{41}$ Rather than the library's organization being based around technical services, public services, and administration, the main divisions would be based on groups of clients within the community (e.g., a department for children, a department for the Spanish-speaking, and so forth). Functional operations would be carried out either by a centralized division or by functional workers in each clientcentered department. In either case, functional operations would be subordinated to the client-centered concerns of the library.

A second and more controversial step would be the removal of the Master's degree requirement for the practitioners of the functional roles. Rather than requiring an M.L.S. for these tasks, a Bachelor's degree in some subject speciality with a designated number of undergraduate library science courses could be enough to qualify a person for basic cataloging and reference work as well as for other functional positions in the library. The functional tasks of librarianship, in other words, would be returned to the holders of undergraduate degrees, while the client-centered roles would be the province of those with higher credentials.

A third consequence of the open systems model raises the issue of the clientprofessional relationship. This relation. ship is most usefully considered if clients are seen as members of an organization, which implies a symmetrical or reciprocal relationship between the two rather than the asymmetrical one that is implied in the individual-practice, fee-for-service setting. If patrons are seen as members of the library's organization, then the issue of client advocacy is more easily resolved, since the members of an organization have natural rights of access to the channels of communication, sources of information, and arenas of decision making that are shared by all other members. Furthermore, it becomes easier, if clients are members, to gain support for resistance to censorship and budget cuts, since such issues will tend to have more meaning and relevance for members of an organization than for those who stand outside its boundaries.

It is obvious, however, that clients would have neither the time nor the desire to concern themselves with the dayto-day operations of the library. Thus, a major part of the librarians' task would be to represent the different points of view of different parts of the community to the library as a whole. At the same time they would also be responsible for representing the activities and the limitations of the library to the segments of the population they serve. Such a role would require thorough knowledge of both the needs of the client groups and the resources in the library and in the community that could be mustered to meet these needs. In addition to this background knowledge, however, the librarians would need to maintain communication between themselves and the groups and individuals that best represent the interests of their entire client group. It would be through these contacts that the clients would receive and maintain their membership in the library organization.

A fourth consequence of the open systems model would change the role of library administrator from one of supervision to one of coordination. The open systems library would have to be much more open to the participation of nonadministrative personnel in the decision-making process. As representatives of the various constituencies of the library, client-oriented librarians would need and demand to have input into all major planning and policy decisions. The role of library administrators in 
decision making would not be to make decisions arbitrarily, but to add their own administrative information (e.g., cost estimates, personnel requirements, and amount of available resources) and to act as mediators between the various viewpoints as expressed by the librarians.

In essence, the library administrator would be the librarian representing the entire community interest. As such a representative, he or she would have to be able to see the long-term results of proposed programs as well as how such programs would fit into the total pattern of library service. It would be the responsibility of the administrator not only to support change that would be beneficial in the long run, but also to resist change that, while appearing effcient and apt in the short term, would prove to be dysfunctional to client services over a longer period of time. The administrator, then, would have to be a persuasive advocate both for change and for moderation.

A fifth consequence of the client-information orientation affects the organizational environment of libraries. In general, four work settings are found among professionals. The first is that of individual practice, which, as we suggested above, is decreasing in importance among other professionals and has never been the norm for librarians.

Three other work settings have distinct organizational structures. There are autonomous professional organizations, such as law firms, medical clinics, and architectural firms. In these cases the professionals themselves determine the organizational structure and are their own source of authority. This setting is not commonplace in libraries although it exists in rare cases. In heteronomous organizations professional employees are subordinated to an external system, e.g., public schools, social welfare agencies, public libraries. Another distinct setting is the professional de- partment, that is, a formal subunit of a larger organization, e.g., the legal department of a corporation. Each of these structural types has implications for professionalism. The autonomous organization is seen as the optimum, the heteronomous as (at least potentially) the minimum, and the professional department as potentially either optimal or minimal. ${ }^{42}$

The issue for librarianship is to identify and to create (cause to be created) the organizational setting in which the open systems model with its client-information dominance can best flourish. It may be true that the typical public library, as a heteronomous organization, is structurally hostile to this new model of professionalism. If this is so, then librarianship must press for structural changes in these agencies. If libraries in elementary and secondary schools and on college campuses are viewed as professional departments, then it is the task of these librarians to insure that these agencies are structured and operated in ways which maximize their client-information dominance.

The sixth consequence of the open systems model would be the need for profound changes in the content, structure, and methodology of library education. As we have already indicated, the deemphasis of the functional activities of the library would ultimately lead to the transfer of courses that deal with these matters in detail from the graduate to the undergraduate level. A graduate program would concentrate its efforts on providing its students with a body of knowledge and the professional attitudes necessary for the client-centered roles of open systems libraries.

The body of knowledge necessary for open systems librarianship can only be delineated in general terms. A client dominant orientation requires substantially more education in the behavioral sciences-both theoretical and appliedthan has been typical in most schools of 
professional librarianship, while a focus on information rather than media requires more education in communications, information science, computer science, and even mathematics. It is clear, however, that librarians serving different types of clients would require different types of knowledge. The education of a science bibliographer who will work in a highly academic environment, for example, must be significantly different from that of the librarian who specializes in providing services for a povertystricken black ghetto.

The vastly divergent educational requirements of open systems librarianship could be met if library schools began to specialize their educational efforts. To follow the example above, one school could concentrate on training science bibliographers while another would train librarians for the ghetto. Such specialization, however, would require that the efforts of all library schools be coordinated into a pattern that would insure training for all clientele groups. Regional systems of library schools might be needed to provide a total pattern of library education. Such systems could share resources and permit students to transfer among schools freely and easily, thus helping each school to share the resources that would normally be available to each one alone, and providing each student the opportunity to plan a program especially suited to his or her interests and needs.

Because library education would thus become broader and deeper, the basic course would probably have to be increased to two years. ${ }^{43}$ There would also have to be a formal recognition of the need for all librarians to renew their education periodically to review and appraise developments in librarianship and related fields. Library schools would be responsible for encouraging students to return to school and should also help develop nontraditional educational programs for those who could not return.
Although changes in the content and structure of library education would be important, they would have to be supplemented by changes in teaching methods if library schools are to provide the best possible education for open systems librarianship. Schein points out that one of the functions of any professional education is to impart the attitudes and values of the profession to its students. ${ }^{44}$ It is not surprising that traditional professional education has relied heavily on the lecture method-a method that, above all else, stresses the $a u$ tonomy of the teacher and inhibits twoway communication between the teacher and the students. The unconscious message of such a method is obviously that once individuals obtain professional authority they do not have to listen to those they serve.

For library schools to educate open systems librarians adequately, they must become open systems institutions themselves. The ideas and experiences of the library school students should be part of the environmental energy and feedback on which the school depends. Thus, the lecture method and its corollaries for evaluating students, i.e., hourcredit graduation requirements and the grading system, would have to be replaced by methods which would encourage students to participate in their education. Graduation requirements would be determined between the individual student and the school, and grading would be replaced by other methods of performance evaluation. In the classroom, methods that emphasize self-initiative and cooperation, such as group projects, discussions, independent studies, and self-paced studies, ${ }^{45}$ would break the near monopoly of the lecture as a teaching method.

The most important innovation, however, would not be these methods themselves; instead it would be the attitude that lies behind them. Library schools, like the libraries they serve, would be- 
come client committed, and this would allow them to serve the library profession and the society as a whole more effectively than has been possible before.

\section{ConClusion}

In choosing a professional model to serve as its ideal, an occupational group demonstrates where its real interests lie. The traditional model of professionalism stresses the importance of the profession as a separate and higher part of society. The professional, for example, is autonomous: his or her professional judgment cannot be questioned by a layman; nor has it been particularly necessary for a professional to consult the layman before making any judgment. In the final analysis the traditional model of professionalism is strongly elitist.
The open systems model of professionalism we have proposed is a more democratic professionalism. It pictures the professional as an integral part of society, depending on it for strength and intelligence as it depends on the professions. The primary purpose of the professions according to this model is not to dictate what clients must do, but to discover what the clients need and to fulfill these needs by using the specialized knowledge and skills that professionals have developed. The open systems model of professionalism should appeal to those occupational groups whose primary concern is to serve the society which has spawned them. Hopefully, librarianship is such a profession.

\section{REFERENCES}

1. For a survey of the sociology of the professions see Ronald M. Pavalko, Sociology of Occupations and Professions (Itasca, Ill.: Peacock, 1971).

2. Abraham Flexner, "Is Social Work a Profession?" School and Society 1:901-11 (June 26, 1915).

3. Morris L. Cogan, "Toward a Definition of Profession," Harvard Educational Review 23:33-50 (Winter 1953).

4. Ernest Greenwood, "Attributes of a Profession," Social Work 2:45-55 (July 1957).

5. Everett C. Hughes, Men and Their Work (Glencoe, Ill.: Free Press, 1958).

6. William J. Goode, "The Librarian: From Occupation to Profession?" Library Quarterly 31:306-20 (Oct. 1961).

7. Howard M. Vollmer and Donald L. Mills, eds., Professionalization (Englewood Cliffs, N.J.: Prentice-Hall, 1966).

8. Talcott Parsons, "Professions," in International Encyclopedia of the Social Sciences (New York: Macmillan, 1968), vol. 12, p.536-46.

9. Amitai Etzioni, ed., The Semi-Professions and Their Organization (New York: Free Press, 1969).

10. Pavalko, Sociology of Occupations and Professions.

11. Bernard Barber, "Some Problems in the Sociology of the Professions," in Kenneth
S. Lynn, ed., Professions in America (Boston: Houghton, 1965), p.17.

12. Goode, "The Librarian," p.307.

13. Howard S. Becker, "The Nature of a Profession," in Education for the Professions, 61 st Yearbook of the National Society for the Study of Education, Part II (Chicago: Univ. of Chicago Pr., 1962), p.33-45.

14. Goode, "The Librarian," p.308.

15. Mary Lee Bundy and Paul Wasserman, "Professionalism Reconsidered," College \& Research Libraries 29:3-26 (Jan. 1968).

16. Greenwood, "Attributes of a Profession."

17. Dietrich Rueschemeyer, "Doctors and Lawyers: A Comment on the Theory of the Professions," Canadian Review of Sociology and Anthropology 1:28-29 (Feb. 1964).

18. "Ocean Hill-Brownsville: The Agony of Decentralization," Nation's Schools 83:2628+ (Jan. 1969); Arthur E. Salz, "Formula for Inevitable Conflict: Local Control vs. Professionalism," Phi Delta Kappan 50: 332-34 (Feb. 1969).

19. Eliot Friedson, "Dominant Professions, Bureaucracy, and Client Services," in William R. Rosengren and Mark Lefton, eds., Organizations and Clients: Essays in the Sociology of Service (Columbus, Ohio: Merrill, 1970) p.75.

20. Richard H. Hall, "Professionalization and Bureaucratization," American Sociological 
Review 33:92-104 (Feb. 1968).

21. Eliot Friedson, "Dominant Professions."

22. Eliot Friedson, Professional Dominance: The Social Structure of Medical Care (New York: Atherton, 1970), p.136.

23. Rueschemeyer, "Doctors and Lawyers," p.28.

24. See William J. Goode, "Encroachment, Charlatanism and the Emerging Profession: Psychology, Medicine, and Sociology," American Sociological Review 25:902-14 (Dec. 1960).

25. Rueschemeyer, "Doctors and Lawyers," p.30.

26. Harold L. Wilensky, "The Professionalization of Everyone?" American Journal of Sociology 70:145 (Sept. 1964).

27. Robert D. Leigh, The Public Library in the United States: The General Report of the Public Library Inquiry (New York: Columbia Univ. Pr., 1950).

28. Frederick G. Kilgour, "The Ohio College Library Center," Datamation 16:87-89 (Jan. $1970)$.

29. Harold Sackman and Norman Nie, eds., The Information Utility and Social Choice (Montvale, N.J.: American Federation of Information Processing Societies Press, 1970); Harold Sackman, Mass Information Utilities and Social Excellence (New York: Auerbach, 1971); Michael A. Duggan, "Computer Utilities-Social and Policy Implications: A Reference Bibliography," Computing Reviews 9:631-44 (Oct. 1964).

30. Edwin B. Parker, "Information Utilities and Mass Communication," in Sackman and Nie, eds., Information Utility, p.53.

31. Florence Field, "Branch Power," Library Journal 94:3409 (Oct. 1, 1969).

32. Bill DeJohn, "Social Responsibilities: What It's All About," American Libraries 2:300 (March 1971).

33. Ludwig von Bertalanffy, General Systems Theory: Foundations, Development, Applications (New York: Braziller, 1968).

34. Walter F. Buckley, comp., Modern Systems Research for the Behavioral Scientist: A Sourcebook (Chicago: Aldine, 1968).
35. Fremont E. Kast and James F. Rosenzweig, Organization and Management: A Systems Approach (New York: McGraw-Hill, 1970).

36. Daniel Katz and Robert L. Kahn, The Social Psychology of Organizations (New York: Wiley, 1966).

37. Ibid., p.19-26.

38. Mark Lefton and William R. Rosengren, "Organizations and Clients: Lateral and Longitudinal Dimensions," American Sociological Review 31:802-10 (Dec. 1966); Mark Lefton, "Client Characteristics and Structural Outcomes: Toward the Specification of Linkages," in Rosengren and Lefton, eds., Organizations and Clients, p.1736.

39. For an explanation of this type of librarian see Kathleen Molz, "Joiner and Goer," Wilson Library Bulletin 38:349-51 (Dec. 1963); and Eric Moon, "A Day in Bedford Stuyvesant," Library Journal 89:3689-93 (Oct. 1, 1964).

40. Robert Burgess, "The Subject Bibliographer: General Background" and "The Subject Bibliographer: Defining a New Role in the University Library," mimeographed (Albany, N.Y.: State University of New York at Albany, School of Library and Information Science, 1970).

41. Theo Haimann and William Scott, Management in the Modern Organization (Boston: Houghton, 1970), p.175-88.

42. Hall, "Professionalization and Bureaucratization," p.94.

43. R. B. Land, "Recent Developments in Education for Librarianship in Canada," $\mathrm{Ca}$ nadian Library Journal 26:36-40 (Jan.Feb. 1969); G. Edward Evans, "School of Library Service at the University of California, Los Angeles," Library Scene 1:2027 (Summer 1972).

44. Edgar H. Schein and Diane W. Kommers, Professional Education: Some New Directions (New York: McGraw-Hill, 1972), p.43.

45. For descriptions of these and other methods, see Ibid., p.109-23. 